\title{
Novel metallic stent designed for endoscopic bilateral stent-in-stent placement in patients with hilar malignant biliary obstruction
}



- Fig. 1 The Hilzo Biliary Moving Cell Stent (BCM Co., Ltd., Gyeonggi-do, South Korea) is a new metallic stent developed for stent-in-stent application, with a smaller cell size $(4 \mathrm{~mm})$ and the same high radial force all around the stent. The smaller cell size is expected to reduce ingrowth, and the high radial force results in higher expansion potential. Source for stent: BCM

In endoscopic bilateral stent-in-stent placement (SIS) in patients with hilar malignant biliary obstruction (HMBO), success depends on second stenting [1-3]. Some metallic stents employed in SIS are designed to be larger to allow easier second stenting $[4,5]$. However, these large cells also increase the risk of ingrowth, resulting in weaker radial force and making it impossible for the stent to expand fully, thereby making second stenting difficult.

The Hilzo Biliary Moving Cell Stent (BCM Co., Ltd., Gyeonggi-do, South Korea) is a new metallic stent developed for SIS with a smaller cell size $(4 \mathrm{~mm})$ and the same high radial force all around the stent. The smaller cell size is expected to reduce ingrowth, and the high radial force results in higher expansion potential ( $\mathbf{F i g . 1}$ ). If the cell is small, second stenting during SIS can be difficult; however, the design of this novel stent allows each cell to expand from $4 \mathrm{~mm}$ to $10 \mathrm{~mm}$ ( Fig.2). This characteristic allows easier passage of the second stent through the cell.
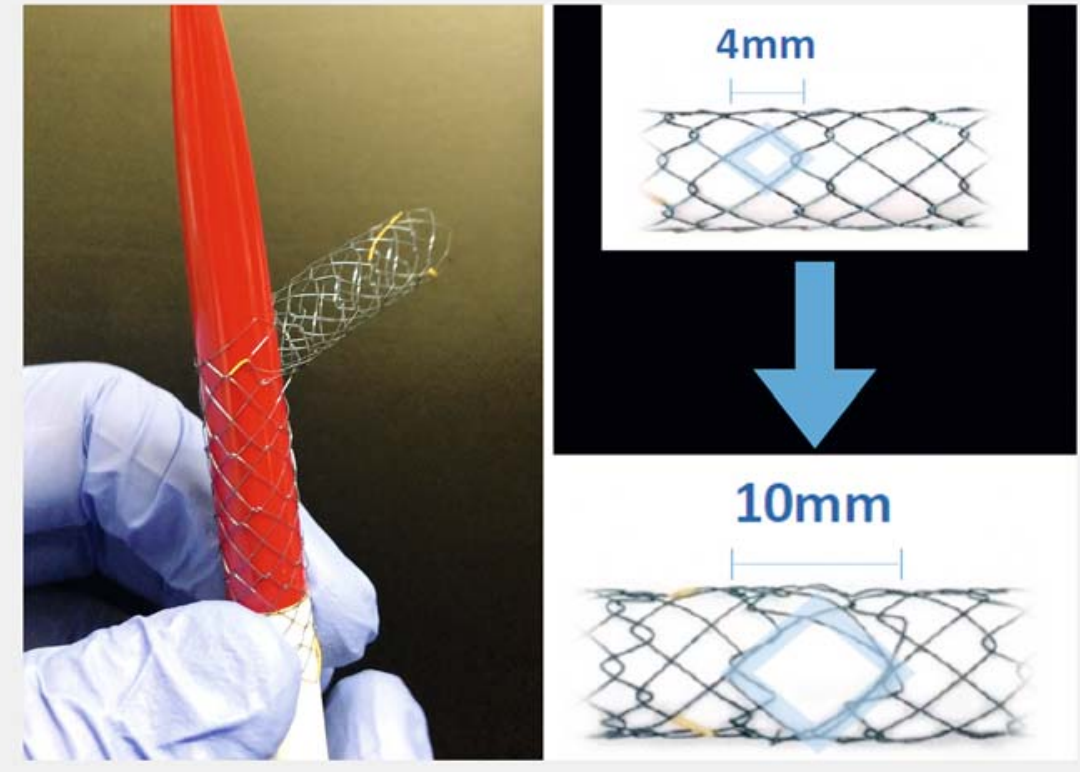

\section{$10 \mathrm{~mm}$}

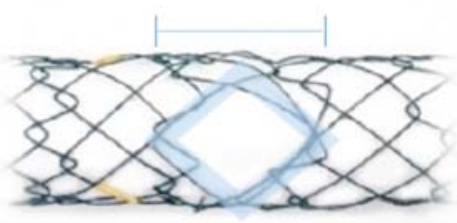

- Fig. 2 If the cell is small, second stenting via a stent-in-stent approach can be difficult; however, this stent allows each cell to expand from $4 \mathrm{~mm}$ to $10 \mathrm{~mm}$. This characteristic allows easier passage of the second stent through the cell. Source for stent: BCM
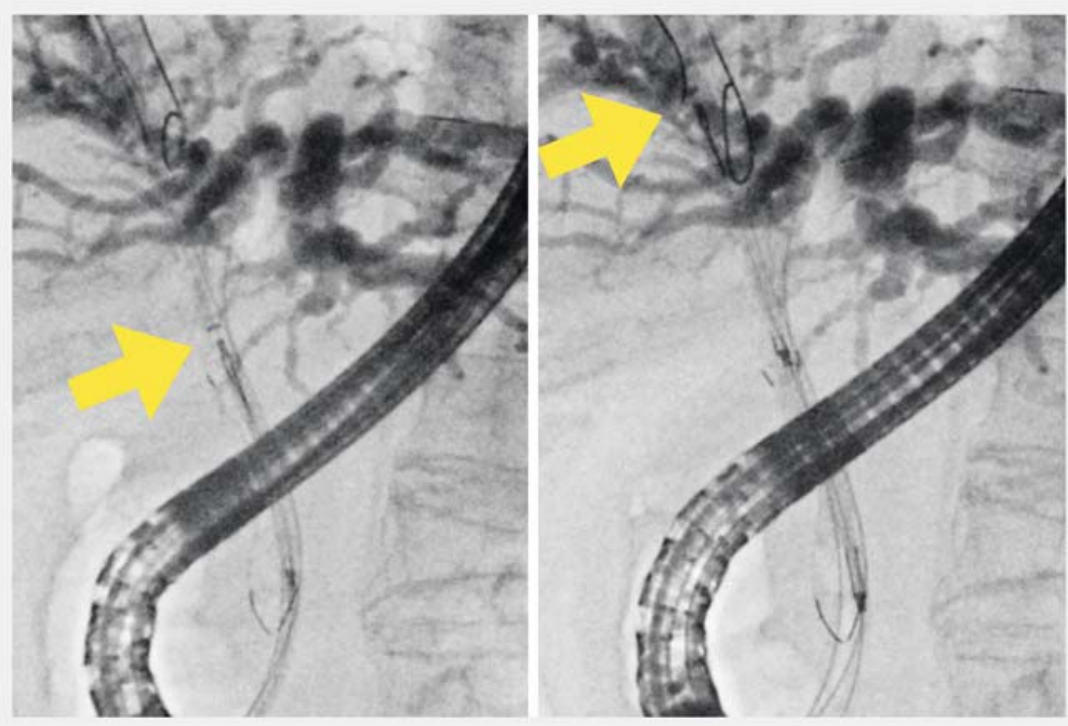

- Fig. 3 We attempted to place the second stent without extending the mesh in the first stent. The tip of the second stent (arrow) was easily passed through the cell without any resistance. 


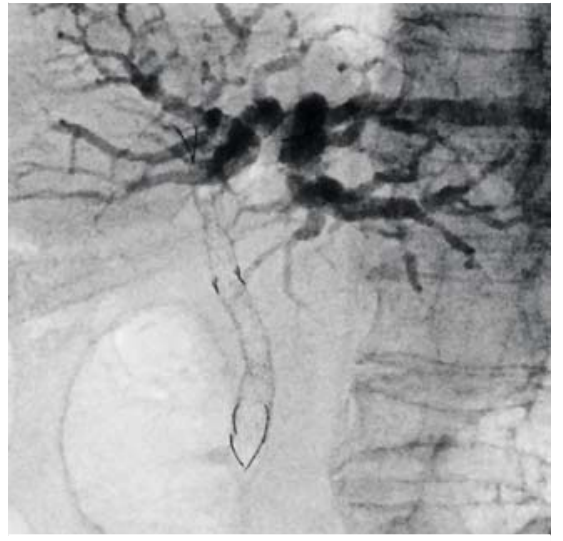

- Fig. 4 Endoscopic bilateral stent-instent placement in patients with hilar malignant biliary obstruction using the novel stent was successful.

An 82-year-old woman presented with obstructive jaundice due to $\mathrm{HMBO}$ and SIS was attempted for drainage. HMBO was confirmed via cholangiography and the first stent was inserted into the left bile duct through the hilar stricture and was successfuly guided to the right bile duct. Next, the contrast catheter was advanced under a guide and passed easily through the cell. We attempted to place the second stent without extending the mesh in the first stent. The tip of the second stent was easily passed through the cell without any resistance, and SIS was

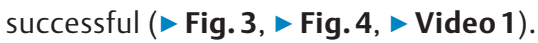
The flexible cells of this novel stent allow expansion and convenience during second stenting in SIS.

This novel concept of each cell having the ability to expand has the potential to become a very useful option for SIS in patients with $\mathrm{HMBO}$.

Endoscopy_UCTN_Code_TTT_1AR_2AZ

\section{Competing interests}

None

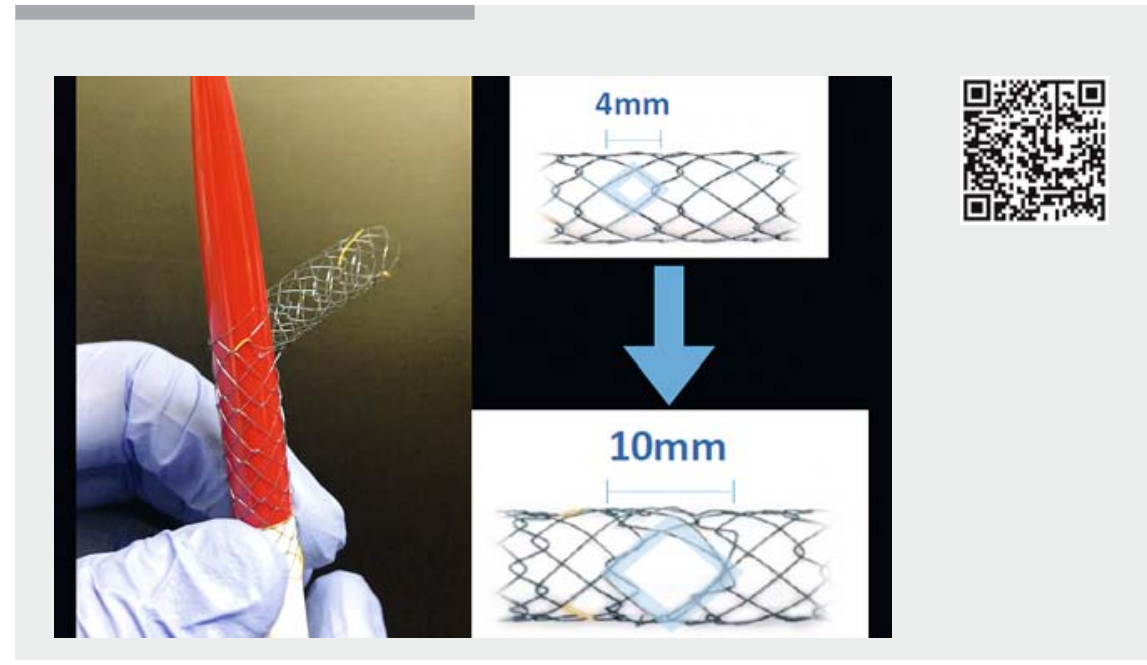

$\checkmark$ Video 1 Novel metallic stent designed for endoscopic bilateral stent-in-stent placement in patients with hilar malignant biliary obstruction. Source for stent: BCM.

The authors

Mamoru Takenaka, Kentaro Yamao, Kosuke Minaga, Atsushi Nakai, Shunsuke Omoto, Ken Kamata, Masatoshi Kudo

Departments of Gastroenterology and Hepatology, Kindai University Faculty of Medicine, Osaka-Sayama, Japan

\section{Corresponding author}

\section{Mamoru Takenaka, MD, PhD}

Department of Gastroenterology and Hepatology, Kindai University Faculty of Medicine, 377-2 Ohno-Higashi, Osaka-

Sayama, 589-8511, Japan

Fax: +81-72-3672880

mamoxyo45@gmail.com

\section{References}

[1] Itoi T, Sofuni A, Itokawa F et al. Current status and issues regarding biliary stenting in unresectable biliary obstruction. Dig Endosc 2013; 25 (Suppl. 02): $63-70$

[2] Lee TH, Moon JH, Choi HJ et al. Third metal stent for revision of malignant hilar biliary strictures. Endoscopy 2016; 48: 1129-1133

[3] Lee TH, Moon JH, Kim JH et al. Primary and revision efficacy of cross-wired metallic stents for endoscopic bilateral stent-in-stent placement in malignant hilar biliary strictures. Endoscopy 2013; 45: $106-113$

[4] Kogure H, Isayama H, Nakai Y et al. High single-session success rate of endoscopic bilateral stent-in-stent placement with modified large cell Niti-S stents for malignant hilar biliary obstruction. Dig Endosc 2014; 26: 93 -99

[5] Lee JM, Lee SH, Chung KH et al. Small cellversus large cell-sized metal stent in endoscopic bilateral stent-in-stent placement for malignant hilar biliary obstruction. Dig Endosc 2015; 27: 692-699

\section{Bibliography}

Dol https://doi.org/10.1055/a-0767-6143

Published online: 23.11.2018

Endoscopy 2019; 51: E30-E31

(C) Georg Thieme Verlag KG

Stuttgart · New York

ISSN 0013-726X

\section{ENDOSCOPY E-VIDEOS \\ https://eref.thieme.de/e-videos}

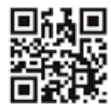

Endoscopy E-Videos is a free access online section, reporting on interesting cases and new techniques in gastroenterological endoscopy. All papers include a high quality video and all contributions are freely accessible online.

This section has its own submission website at https://mc.manuscriptcentral.com/e-videos 